\title{
A public theological approach to the (im)possibility of forgiveness in Matthew 18:15-35: Reading the text through the lens of integral theory
}

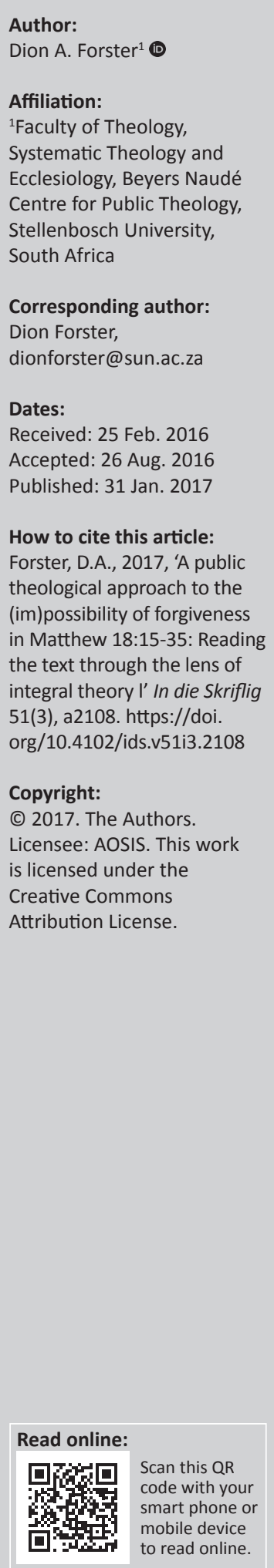

Some 20 years after the dawn of participative democracy, there is little noticeable or substantial change in the living conditions of the average South African. The country remains divided by race, class and economics. Poverty, inequality and racial enmity remain looming challenges to human flourishing and social transformation. Some have begun to ask whether forgiveness for the sins of colonialism and apartheid are possible. This article engages with the (im)possibility of forgiveness as it is presented in Matthew 18:15-35. In particular, it does so from the bilingual perspective of a public theological engagement with the text and its contemporary readers in South Africa. By reading the text from an integral All Quadrants All Levels (AQAL) approach this article extrapolates a textured understanding of forgiveness that 'possibilises' the (im)possiblity of forgiveness between racially and socially divided groups of readers.

\section{Introduction}

Matthew 18:15-35 offers a number of significant theological insights into understandings of forgiveness. This article explores the complexity of forgiveness as it is presented in the social and historical context of Matthew 18:15-35 and the contemporary context of a largely unreconciled South African society 20 years after the dawn of participatory democracy. Is biblical forgiveness possible among black and white South Africans given the nature of the crimes perpetrated during the colonial and apartheid eras in South Africa? ${ }^{1}$ The Institute for Justice and Reconciliation (IJR) recently reported that (see Hofmeyr \& Govender 2015):

While most South Africans agree that the creation of a united, reconciled nation remains a worthy objective to pursue, the country remains afflicted by its historical divisions. The majority feels that race relations have either stayed the same or deteriorated since the country's political transition in 1994 and the bulk of respondents have noted income inequality as a major source of social division. Most believe that it is impossible to achieve a reconciled society for as long as those who were disadvantaged under apartheid remain poor within the 'new South Africa'. (p. 1)

One of the challenges of the rhetoric of forgiveness and reconciliation is that it assumes an end point, i.e. an ideal located in a yet unreached future, while the present remains unchanged. The research suggests that what is needed is a more nuanced understanding of forgiveness as it is seen in Matthew 18:15-35. ${ }^{2}$ It not only places an emphasis on the desired goal, but emphasises the journey towards that goal (the series of encounters and relationships that are necessary in the unchanged present to work towards a changed future).

In terms of the process of intercultural Bible reading that shaped the larger project of which this research is a part, Nussbaum (2010) says:

$[T]$ he ability to imagine the experience of another - a capacity almost all human beings possess in some form - needs to be greatly enhanced and refined if we are to have any hope of sustaining decent institutions across the many divisions that any modern society contains. (p. 10)

The bilingual nature of this study frames it within a public theological approach. ${ }^{3}$ In order to complete the aforementioned task, it will be necessary to explicate aspects of the Matthean narrative

1.See the key findings of the IJR report in SA Reconciliation Barometer 2015: National Reconciliation, Race Relations, and Social Inclusion (Hofmeyr \& Govender 2015:1-2).

2.See Marius J. Nel's discussion in Interpersoonlike vergifnis in Matteus 18:15-35 (2015a) on the complexity of forgiveness in this particular text with reference to Before forgiveness: The origins of a moral idea (Konstan 2010). This article and the book it engages, argue that the contemporary notion of interpersonal forgiveness cannot be equated in their entirety to understandings of the social and communal processes of forgiveness described within the ancient Near East (and Matthew's Gospel).

3.The discipline of public theology is gaining prominence in scholarly theological discourse. There are a variety of understandings of the discipline of public theology and the approach of the public theologian. However, they seem to converge in the idea that theology has a valid and necessary role to play in public discourse. That matters of public concern should be engaged theologically (both for the sake of making a public theological contribution, but also to reflect upon and shape our theological perspectives on the world, 
of forgiveness through a careful and critical exegesis of the text and carefully consider how contemporary readers may engage complex notions of forgiveness in the text.

This article will offer an explanation of the proposed hermeneutic lens for this study, namely integral theory (i.e. Ken Wilber's AQAL integral philosophy). ${ }^{4}$ A case will be made for the applicability and value that comes from approaching forgiveness as it is presented in Matthew 18: 15-35 from an integral perspective. This will serve to texture our understanding of both the text and how contemporary readers understand forgiveness in reading this text.

This research forms part of a larger project. As such, it does not claim to be conclusive. Rather, it aims at highlighting a novel and theologically bilingual approach to studying biblical texts from a perspective that draws upon the insights gained from interdisciplinary and trans-disciplinary methods in an increasingly complex environment in the public of the theological academy, the public of the church and the public of society at large. ${ }^{5}$

Finally, it remains to be said that this research forms part of a larger research project that was shaped under the guidance of Professor Jan van der Watt. Van der Watt has frequently pressed and advanced the boundaries of biblical scholarship with ethical intent (cf. Van der Watt 2006; 2013; Van der Watt \& Malan 2006). As such, this contribution is presented in gratitude and honour of his scholarly and personal contribution to my life and career.

\section{Why a public theological approach to forgiveness in Matthew 18:15-35?}

The notion of public theology is gaining prominence within theological discourse. Smit (2013:11-12) points out that the development of the notion of public theology is tied to social, historical and philosophical developments in the various publics of society. The public of the theological academy is facing questions about why and for whom theological research is being done. The re-emergence of religious and theological sentiments in the public of general society present new questions to the Christian faith, the church and theological scholarship (Smit 2013:11-12). Changes to the role

\section{(footnote 3 continues...) \\ our own lives and God). Please refer to Smit's article The Paradigm of Public The own Iives and God). Please refer (2013) for a help fut historical overvicu philogy Origins and Development (2013) for a helpful historical overview and philosophical analysis of the development of the term public theology and development of the discipline of public theology in theological discourse. It is also worth noting that the discipline and terminology are contested in South African theological discourse. Please see the Maluleke (2011) and Koopman (2011) as two prominent examples of the diverse perspectives on the role and place of public theology in South Africa. Tshaka (2014:4-5) has a very insightful analysis of the debate in his article $A$ perspective on notions of spirituality, democracy, social cohesion and public theology in which he offers a balanced and nuanced view of the role of public theology in the South African context.}

4.Wilber's work is not without its critics. In particular the work of Kirk Schneider (cf. 1987:196-216; 1989:470-481; 2012:120-123) has pointed out some deficiencies and weaknesses in Wilber's integral theory over the last two decades. Some of these aspects will be addressed in the sections that follow. However, notwithstanding such critique, there is sufficient credible acceptance of Wilber's work to be used in such critique, there is sufficient credible acceptance

5.For examples of such interdisciplinary and trans-disciplinary studies see the Intercultural Biblical Hermeneutics Series (De Wit 2012; Jonker 2015; Van der Walt 2014). and witness of the Christian church throughout the world are causing denominations and congregations to ask questions about the 'church's identity, mission and work as a public that shapes both thought and action to varying degrees in differing contexts (cf. Sigurdson 2012:3-9; 2013:361-362; Taylor 2009:325-332).

What is needed in these shifting contexts is a more nuanced and carefully textured understanding of the notion of the 'publics' in public theology. Koopman rightly points out, in the line of David Tracy (1975:287; cf. Ruiter 2007) and Jürgen Habermas (Dreyer \& Pieterse 2010; Smit 2007), that the language, intention and tone of theology changes (and needs to vary) depending on the public from which it emerges and the public for which it is intentioned. Habermas explains the development of the notion of the various 'publics' of society and the formation of various 'public opinions' in society by means of his concept of critical discourse theory (cf. Habermas 1985; 1991; Ruiter 2007:431-436). Following this logic Tracy suggests that there are at least three 'publics' that emerged in which theologians can and should make a contribution. These are the public of the church, of the academy and of society in general (Tracy 1975; 2014). It is in this sense that public theology becomes inter-disciplinary and even transdisciplinary in approach. It seeks some measure of theological bilingualism, namely the conducting of credible, rigorous and critical theological engagement (in the public of the theological academy) that can be translated into the public of the church or the public of general society. ${ }^{6}$

Koopman (1998) notes:

Although the Scriptures do not give blueprints for our societal problems, our ideologies are corrected by the light the biblical principles provide. In South Africa, where the race factor has also determined how people understand the Bible, it is of utmost importance that people listen jointly to the Word to discover God's will for us today. This joint listening to the Word wills us to develop a common story which belongs to all of us. This common heritage corrects our racial ideologies, but also liberates, encourages and energizes us to work for a new society which reflects something of the biblical ideals. (p. 165)

This reasoning suggests that the biblical text has a communicative ethical impact on society (cf. Van der Watt 2014:7). ${ }^{7}$ The study has consequences for all three publics: the academy, the church and society at large.

\section{Why Matthew 18:15-35?}

Why was Matthew 18:15-35 chosen as an exemplar text in stating the argument of this article? ${ }^{8}$

\footnotetext{
6.For a detailed discussion of the complexity of building a hermeneutic bridge between the world and intention of the original author and the contemporary reader, please see (Lategan 2015). Smit writes about this hermeneutic bridge saying, "'The continuity of our actions with the biblical documents does not lie in words, but - with reference to Jüngel - in the quality of our Verhalten, our presence, our attitude" in other words, in our life together, as integral part of our interpretation' (Smit in Lategan 2015:9-10).

7.See for example Austin (1975:3-5) on the performative intention of communication as well as Searle (1969:155) who emphasised the illocutionary intent of written communication. Also see Viljoen (2014:9-11) as an example of porformative communication. Also see viljoen (2014.9-11) as an example of performative communication with its social and ethical implications for the hearer or reader.

8.Because of the limits of a publication of this sort I shall not be able to do a thorough exegesis of Matthew 18:15-35. I shall, however, just make reference to the
} 
The Christian scriptures have numerous teachings on forgiveness. It is undeniably an important concept in the New Testament as recent studies in the field have shown (Nel 2002; cf. Hägerland 2011; Konstan 2010; Mbabazi 2013).

Moreover, there are many texts that deal with the notion of forgiveness from a variety of perspectives (theological, social, restitution, grace, developmental). The most recent and extensive project on forgiveness in the New Testament is Jesus and the Forgiveness of Sins of Hägerland (2011). Within the Matthew studies, the most complete studies on forgiveness are by Nel $(2002 ; 2013 ; 2014 ; 2015 b)$ and Mbabazi (2013). ${ }^{9}$

Matthew 18:15-35 was chosen for this project, because it presents a set of three narratives that approach the complex topic of forgiveness from differing perspectives. Of interest in this article was the importance of forgiveness as a spiritual and theological concept (i.e. forgiveness as a process that restores relationships with God) (Mbabazi 2013:153-158). Equal to this is the text's emphasis on forgiveness as a social concept (i.e. the restoration of relationships within a broken community) (Duling 1999:6; Senior 1987:403). The interplay between the intent of the original author and the originally intended reader's context, and the current readers, allows for a fascinating study. ${ }^{10}$

This section (Mt 18:15-35) deals with the concepts of alienation and forgiveness with a strong focus on power relationships within the community (for a detailed discussion of community ethics in Matthew please see Van der Watt \& Malan 2006:23-45). As Van der Walt (2014:2) reflects, employing a text like this allows the text to function 'simultaneously as a conversation starter for intercultural conversation and as a reflective surface' that allows the participants to 'reflect on their own contemporary and contextual experiences'. While the Matthean context and the contemporary South African situation are vastly different, it is plausible to identify some coherence in social aspect between these communities with their respective 'in group' and 'out group' tensions (cf. Kok 2014:1-9).

A further reason that makes Matthew 18 suitable for the intended purpose is that it finds its place within the community discourse of Matthew's Gospel (Senior 1987:403-407; Weren 2006:171-200). The larger project aimed at facilitating a process of engagement between two divided Christian communities. Matthew 18 is a discourse with a focus on community ethics and social harmony. ${ }^{11}$ As such, it is of

\footnotetext{
(footnote 8 continues...)

necessary exegetical aspects of the text to show why it is an important text to use in presenting an integral public theological engagement with forgiveness in biblical scholarship and the publics of the church and broader society.
}

9.The topic of forgiveness in the biblical text is extremely broad and extensive. For a very helpful scholarly overview of this area please see, Gowan's The Bible on Forgiveness ( 2010) and Nel's Vergifnis en versoening in die evangelie volgens Matteus (2002).

10.For a creative example of research that lays a credible groundwork for such engagement see Wasserman's Listening past difference (2016).

11.There are numerous excellent studies of the structure of Matthew's Gospel (literary, narrative, geography, topical, conceptual, et cetera. Please see the following overview of Bauer (1989). There is general acceptance of the fact that benefit to the process of explicating notions of forgiveness as well as the cost of forgiveness.

The conceptual thrust of harmony in the Christian community, as expressed in Matthew 18, is triggered by the question that is asked in verse 1, namely 'Who is the greatest in the kingdom of heaven?'.12 Peter's question in verses $21^{13}$ reiterates this theme, 'Then Peter came and said to him, "Lord, if another member (brother) of the Church (family) sins against me, how often should I forgive? As many as seven times?"' It could be argued that Matthew 18 presents Jesus' formulated reply to these questions in various parables and accumulated sayings.

When Jesus places the child in the middle of the group and tells the disciples that they will not enter the kingdom of heaven unless they are like a child (Mt 18.3), he destabilises the accepted social order and so introduces a new approach to the structuring of the community based on kingdom principles rather than social standing or cultural rights (Senior 1987:403; Duling 1999:6).

The notions of community and forgiveness in Matthew 18 (especially vv. 15-20, 21-22 and 23-35) were thus important in this research. Naturally, these sections cannot be read in isolation from the rest of the chapter or, indeed, the entire Gospel. However, the foci on forgiveness and harmony in the community are key themes and a necessary delineator.

Thus, Matthew 18 has been widely identified as a discourse for the church or a discourse for the community of disciples (Senior 1987:403-407; Weren 2006:171-200). The sections on forgiveness dealing with sin and the parable of the unforgiving servant, tie together a number of important themes that run through the chapter (Mbabazi 2013:136-216; Nel 2015a:3; Reimer 1996:268-271). These include the characteristic values that members of the community should extol (such as humility - vv.1-7; restraint and discipline - vv. 8-9; mercy and grace - vv. 21-35). In addition, there are a number of theological insights that build throughout Matthew 18 towards the final parable (the eschatological expectation of salvation or judgement - vv. 3, 8, 9, 35; the relationship between actions in this life and God's eternal Kingdom - vv. 1, 10, 14, 18-20, 23, 35) (Davies \& Allison 1991:789).

An overt theme of verses 21-35 appears to focus on forgiveness that contributes towards the wellbeing of the community, (cancellation of a debt, setting a person free: $\dot{\alpha} \varphi \eta \dot{\sigma} \omega$ - v. 21; $\dot{\alpha} \varphi \tilde{\eta} \kappa \varepsilon v-$ v. 27; $\dot{\alpha} \varphi \tilde{\eta} \tau \varepsilon-$ v. 35). However, this theme is part of the larger aim of the whole chapter, namely the facilitation of healthy relationships in the community of disciples (Nel 2015a:5).

\footnotetext{
(footnote 11 continues...)

Matthew 18 stands as a discourse on community (with some variation on the structuring of the contents of the chapter). Please also see the excellent discussion of ethics and ethos in Matthew's Gospel in 'Identity, Ethics and Ethos in the New Testament, Volume 141' (Van der Watt \& Malan 2006:27-27, 40-45).

12. Unless otherwise stated all references to the Bible will come from the New Revised Standard Version.
}

13.All verse-references refer to Matthew 18. 
Taking the preceding discussion into account, Matthew 18:15-35 was deemed valuable for an integral public theological reading for the following reasons.

\section{The topic of the text}

It has a strong thematic emphasis on forgiveness in various forms running through its narrative. Particularly, this passage focuses on issues of social harmony, relationships, ${ }^{14}$ discipline in the church and community forgiveness (Carter 2005:361-376; Hagner 1995:515-516, 528-529, 534-537; Mounce 1995:173-174; Overman 1996:262-276; Viviano 2007:211-219; Zimmermann \& Dormeyer 2007:448-453). The thematic and theological content of this text is both necessary as a theological informant for the development of an understanding of Christian forgiveness as well as functioning as a helpful framework within which to structure the intergroup engagements around forgiveness for contemporary Christian readers.

\section{The layered understanding of forgiveness in the text}

The text offers a layered understanding of forgiveness that touches on the four general areas of human experience and reality. Moreover, this text presents a nuanced understanding of the complexity of forgiveness that is in keeping with the theoretical and theological perspective of the research. Wilber's AQAL theory shows the importance of diverse and layered understandings of reality that cover all four aspects of human identity and being (Paulson 2008). This text allows for such an understanding of the complexity of forgiveness. It is contented that forgiveness is a complex process of shifting from one set of realities and experiences to another through various phases of social interaction and inner change (Duffy 2009; Gobodo-Madikizela 2009; Hannoum 2005; Kaplan 2008; Ricoeur 2009; Vosloo 2015). Lastly, this text has sufficiently detailed social information for the application of theories to understand the complexity of inter-group social identity (Tucker \& Baker 2014:147-173) and inter-group contact (Brewer \& Kramer 1985; Pettigrew 1998; Pettigrew \& Tropp 2011).

\section{Mimesis and performative ethical implications}

Van der Watt (2014) makes the point that in the biblical worldview and in the broader culture at the time of the writing of the Gospels, mimetic texts based their transformational capital on more than just theological content. Such texts also focus on social expectation (Van der Watt 2014:7). They present with the clear expectation that " $n$ persoon volgens sy identiteit sal optree. Hierdie aspek van antropologie staan al vanaf Sokrates in die sentrum van diskussie' ['... a person will act (behave) according to his identity. This aspect of anthropology has been at the center of (ethical) discussion since Socrates'] (Van der Watt 2014:7, [author's own translation]). The expectation is that the readers will not only understand the grammar, syntax and narrative of the text, but that they will respond to the narrative mimetically.
They are expected to respond in a manner that is appropriate to their time and context (Van der Watt 2014:8).

This is illustrative of an aspect of Matthew's style displayed in the discourse of the Sermon on the mount where Matthew's Jesus points out that faithfulness to God and true Christian discipleship is not just a matter of obeying the law, but consists in mimicking the character of the loving God that is fulfilled in the person and life of Jesus (Davies \& Allison 1988:507, 541; Garland 1999:62-77; Morris 1992:106-112; Overman 1996:77-84; Talbert 2010:72-73). ${ }^{15}$ One could argue that Matthew employs the strategy of mimesis throughout the gospel and, particularly, in Matthew 18 to convey meaning to the reader through the content of the text, the structure of the narrative, the genre of the text and its embeddedness in a socio-historical network of shared meaning. With regards to the ethical implications of this, Van der Watt (2014) writes:

Dit beteken dat die etos wat die algemeen aanvaarde gedrag binne die Christengemeenskap verteenwoordig, onder andere veronderstel dat die Vader en Jesus mimeties aan gelowiges, as kinders van God, gebind was ... Mimesis word dus verwag, omdat die aangesprokenes hulleself binne die familie bevind. Die veronderstelling is dat binne die betrokke sosiale raamwerk mimeties opgetree moet word. Dit is moontlik omdat mimesis nie 'n sosiale model is nie, maar eerder 'n spesifieke gestruktureerde houding weerspieël. [This means that the ethics that represent the generally accepted behaviour within the Christian community assumes, among other things, that the Father and Jesus are bound mimetically to the believers, as children of God ... Mimesis is thus expected since those who are being addressed find themselves within the family. The assumption is that persons will behave in a certain manner within this mimetic framework. This is possible since mimesis is not a social model as such, but rather a representation of a specific structural attitude (ethos)]. (p. 8, [author's own translation])

\section{Why Ken Wilber's Integrative AQAL approach?}

Ken Wilber is well regarded as a philosopher of contemporary social identity theory. His work is widely cited in this field (Esbjörn-Hargens 2009:33). Naturally he has his critics (cf. Schneider 1987:196-216; 1989:470-481; 2012:120-123). Notwithstanding such critique, there is a sufficient scholarly acceptance of his contribution to utilise it in the manner proposed here.

Wilber (in Visser 2003) offers the following summary of integral AQAL theory:

The word integral means comprehensive, inclusive, nonmarginalizing, embracing. Integral approaches to any field attempt to be exactly that: to include as many perspectives,

15.There is a rich corpus of study on this topic. Two points of illustration will suffice: first is the structural narrative of Matthew's Gospel in which Jesus is presented as the fulfillment of righteousness (Mt 3:1-4:17), followed by Jesus' discourse on true righteousness (Mt 4:18-8:1). These set the scene for the development of a new righteousness (Mt 4:18-8:1). These set the scene for the development of a new form of faithfulness and righteousness that progressively unfolds in Matthew's Gospel in accordance with 5:17. This theme is echoed clearly in our passage in Matthew 18:21-22. A second example is the use of 'but/and' $(\delta \dot{\varepsilon})$ from Matthew :22 onwards where Jesus establishes himself as the fulfillment of the law (Davies \& Allison 1988:541). The point is that Jesus is not abolishing the law, but fulfils it. Thus, if the disciple follows both the teaching and the example of a faithful and loving life as seen in Jesus (mimesis), she or he cannot go wrong (Davies \& Allison 1988:507). 
styles, and methodologies as possible within a coherent view of the topic. In a certain sense, integral approaches are 'metaparadigms,' or ways to draw together an already existing number of separate paradigms into an interrelated network of approaches that are mutually enriching. (pp. xii-xiii)

According to integral theory, there are four irreducible perspectives that must be taken into account when attempting to understand an aspect of reality. They are, the subjective (I), the intersubjective (we), the objective (it) and the interobjective (its) (see Figure 1). In its most basic form the principle of integral theory expresses that everything can be considered from two basic distinctions: first: from an inner and an outer perspective; and second, also from an individual and a collective perspective.

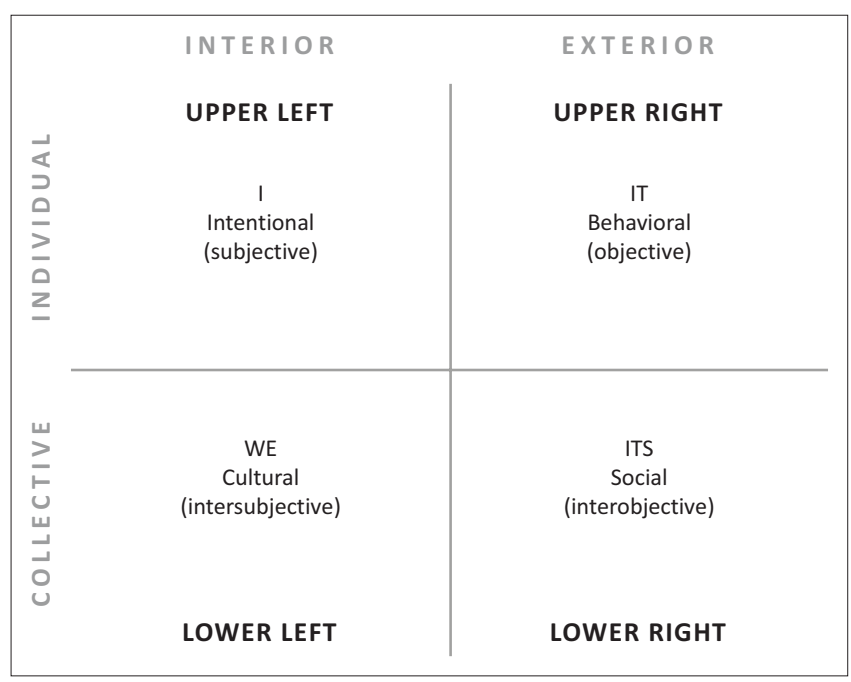

Source: (Esbjörn-Hargens 2009:36)

FIGURE 1: The four quadrants of identity and meaning in AQAL theory.

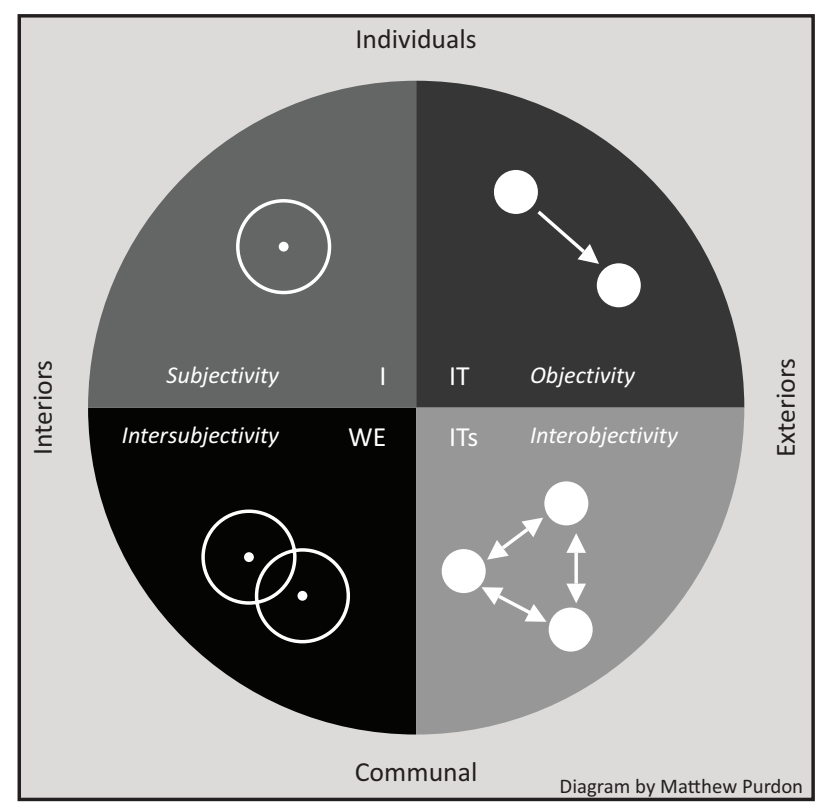

Source: (From De Quincey 2006:206)

FIGURE 2: Subject and object relations in AQAL theory.
This approach provides both language and a thought construct around which to develop a nuanced understanding of the multifaceted complexity of social identity.

Previous research (cf. Forster 2006) has collated data that suggests that these four aspects (quadrants) correlate with or cohere to dimensions of reality. For example, all living things have some measure of subjectivity (an interior identity Upper Left [UL]) as well as unique observable behaviours that express this interior life (an exterior identity - Upper Right [UR]). In addition, the interior identity of individuals is shaped by being in relationship to other people and other things (being male, being English, living in Africa, etc.). These collective interior elements are generally classified as intersubjective realities, experienced as a common culture, value or belief system (Lower Left [LL]). The exteriors are known as ecological and social systems (Lower Right [LR]). To understand the locus of identity relationships in each of the four quadrants, please refer to Figure 2.

Snyman (2002) notes that:

The vast networks and contexts of one's cultural community serves as the intrinsic background in which ... thought arises, and shapes thought itself in the life and upbringing of the thinker. (p. 93).

It should be borne in mind that culture itself has material components just as thoughts have material components (e.g. the individual thought [UL] is related to the individual brain [UR]). For the original thought itself to be possible, certain social, external, realities need to present (e.g. not only the culture of the thinker [social inward - LL], but also social structures that make such thoughts possible, e.g. geography, etc. These are all LR expressions of the holon, because they are social, external, necessities). Wilber refers to these LR elements as the 'social action system' and 'concrete material components', which are necessary for the actual worldview within which the thought arises to exist.

The importance of this interrelated understanding of the four dimensions of reality suggests that responsible scholarship cannot 'collapse' all of the elements of an understanding of forgiveness into one quadrant.

For engaging Matthew 18:15-35 in order to gain a fuller understanding of complex Christian forgiveness, the value of the AQAL integral approach is clear. The AQAL hermeneutic approach will be brought into conversation with the text to illustrate the textured variety of interpretive opportunities.

\section{An AQAL integral approach to Matthew 18:15-35}

This passage highlights the deficiency of a flatland ${ }^{16}$ reading of forgiveness. The introductory question posed by Peter

16.Flatland is an expression coined by Ken wilber that explains the process of collapsing one's understanding of reality into either the interior realm collapsing one's understanding of reality into either the interior realm
(psychological, spiritual) or the exterior realm (science, politics, sociology). Wilber (1998:124ff.) suggests that one of the greatest achievements of the Enlightenment was the differentiation of the three realms of being as I (UL), We (LL) and It 


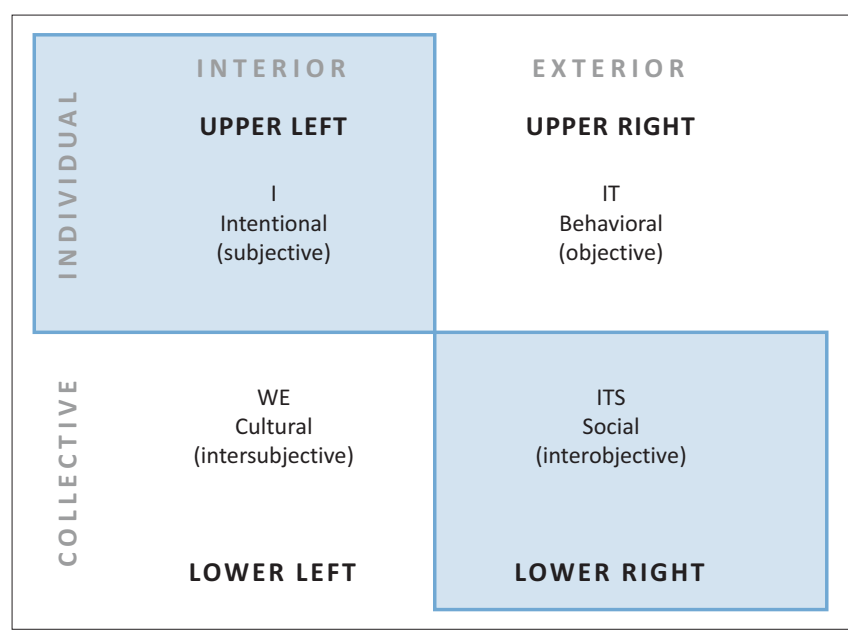

FIGURE 3: Upper Left, Lower Right.

(v. 21) places forgiveness within the context of the Christian community: 'Lord if my brother ... (o $\dot{\alpha} \delta \varepsilon \lambda \varphi o ́ \varsigma \mu \nu v)$ '. What we see in this question is an individual (UL) attempting to find meaning in the midst of inner conflict ('how many times should I forgive?'). This was likely to have been brought on by disharmony in the community (LR) considering the place in which this question is found in the narrative of Matthew 18 , that is, just after verses $15-20$ which presents a process for dealing with sin or wrongdoing in the community. Please refer to figure 3 for a diagrammatic representation of the domain location of the theological understanding of forgiveness in this regard.

An AQAL hermeneutic highlights Matthew's approach to the intricacy of forgiveness. Jesus's answer to Peter's question adds a dimension of complexity, namely the reliance of the Matthean community on the Jewish law (LL), (vv. 21b-22, 'how often should I forgive? As many as seven times?' Jesus said to him, 'Not seven times, but, I tell you, seventy- seven times'). Religious law is based upon a shared understanding of morality that arises from a set of theological convictions about what is just and right, and what is unjust and wrong (LL). Figure 4 shows the further domain complexity of forgiveness in that it operates in three quadrants of theological meaning and identity.

One of the suggested intentions of Matthew's Gospel was the re-establishment of a new social and religious order based on the understanding that Jesus was the fulfilment of the Jewish law (Davies \& Allison 1988:507, 541; Garland 1999:62-77; Morris 1992:106-112; Overman 1996:77-84; Talbert 2010:72-73). Jesus is presented as the fulfilment of righteousness that is required by the law (Mt 3:1-4:17) (UL and UR), followed by Jesus' discourse on true righteousness (Mt 4:18-8:1). These set the scene for the development of a new form of faithfulness (righteousness) that progressively unfolds in Matthew's

(footnote 16 continues...)

(where 'It' includes both right hand columns of the four quadrants). As a result of this, Wilber sees the task of late modernity (or post-modernity) in relation of this, Wilber sees the task of las 'fladernity - not simply as replacing atomism with holism, but to integrate the This task is urgent, becthe This task is urgent, because there is a great deal of subtle reductionism in the dualistic worldviews of both modern atomism and postmodern holism (cf. Forster 2006:214-217 for a more detailed discussion of these concepts).

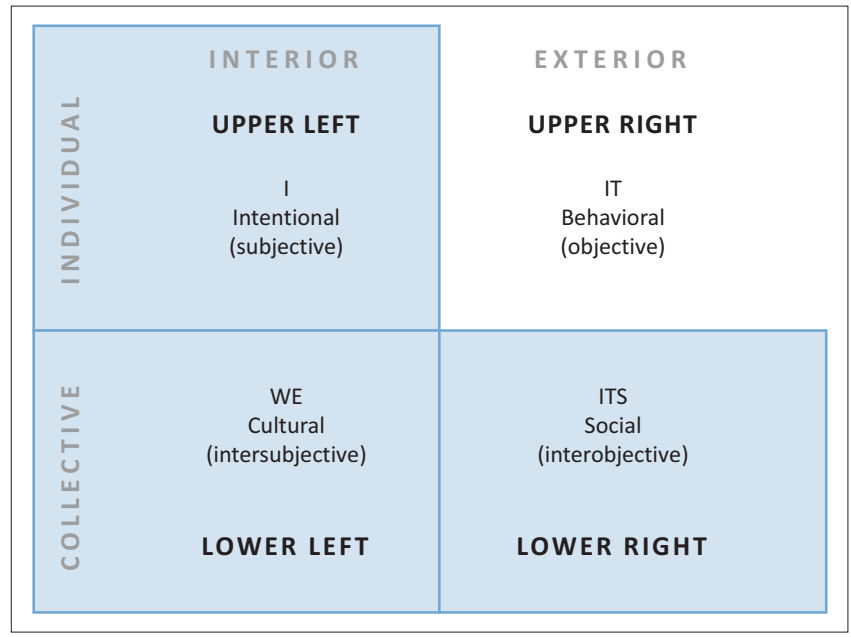

FIGURE 4: Upper Left, Lower Left, Lower Right.

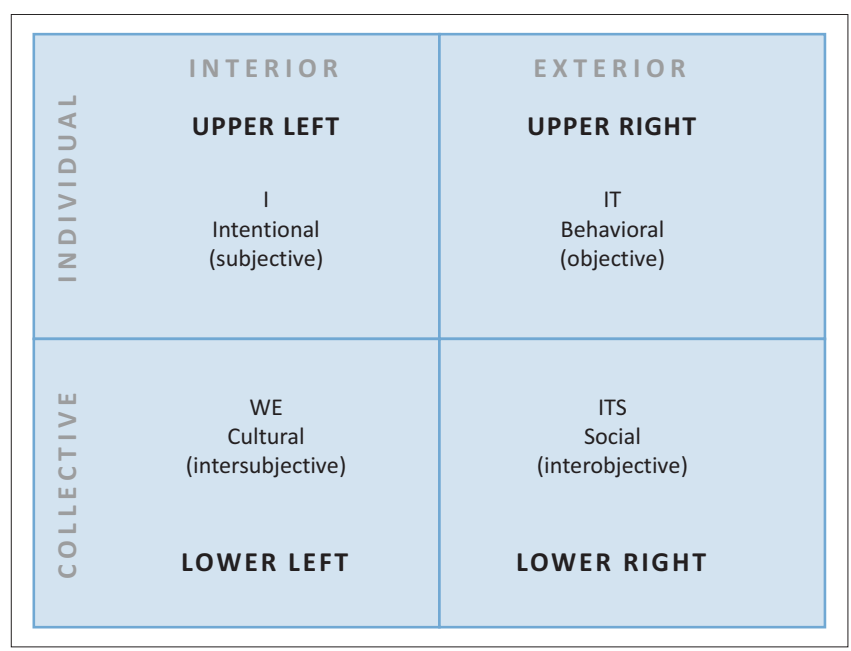

FIGURE 5: All Quadrants.

Gospel in accordance with 5:17 (LL and LR). This theme is echoed in Matthew 18:21-22. A second example is the use of 'but/and' $(\delta \dot{\varepsilon})$ from Matthew 5:22 onwards where Jesus establishes himself as the fulfilment of the law (Davies \& Allison 1988:541). Jesus is not abolishing the law, but rather fulfils it. Thus, if the disciple follows both the teaching and the example seen in Jesus (mimesis), linked to values (UL) and action, (UR), she or he is faithful as a believer (UL), a member in good standing of the new community (LL). Through their beliefs (UL) and actions (UR), the values and virtues of the new community (LR) are establishing and upholding (Davies \& Allison 1988:507). The result is that Matthew presents the shift in identity from individual belief to an integrated understanding of the complex interplay of individual identity (UL), social identity (possibly theological identity) (LL), individual action (UR) and social harmony (LR). The graphic representation in Figure 5 displays the possibility of an integral understanding of forgiveness that operates in all for quadrants of theological identity and meaning.

This approach highlights that the intended social cohesion and faith life integration that is advocated in this passage, deals with all four of the AQAL life dimensions. 
Social harmony and Christian faithfulness require forgiveness (illustrated in vv. 21-22 \& v. 35). In fact, where there is agreement (unity) the Lord promises to be among the members of the community (vv. 19-20). Thus, forgiveness cannot be a purely personal matter (UL), although it requires a personal engagement with the particular if there is some sin that is disturbing personal relationships and community harmony. The use of the adjective póvov in verse 15 emphasises the need for courtesy in the personal engagement, that is, not to publically humiliate or manipulate the individual. At the same time it shows that personal engagement is important, 'go' (ขँ $\pi \alpha \gamma \varepsilon$ imperative, present, active, 2nd person, singular) is an UR action of the individual, that is, 'you must go [alone to him]', whereas 'between you

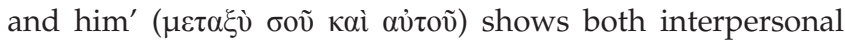
presence (LR) and the intention of dealing with the conflict in a shared interpersonal value space (LL) $(\mu \varepsilon \tau \alpha \xi \dot{v}$ is a preposition that can refer either to a physical location as in Ac 12.6, 'he was sleeping between two guards', or as an associative interpersonal space as in Ac 15.9, 'he did not discriminate between us and them'). The flow of the narrative in verses 15-17 shows a progression of identity location between the individuals (the sinner and the sinned against, indicated by the phrase $\dot{\alpha} \delta \varepsilon \lambda \varphi \varsigma_{\varsigma} \sigma o v$, indicating relational identity location, namely, the self and the other who is related to the self, who is also the cause of personal offence). If the

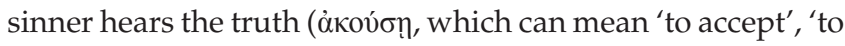
believe' and 'respond') of the sinned against the person in the personal engagement (

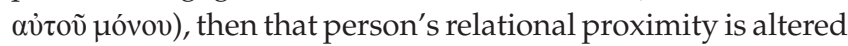
from that of an outsider (v. 17, ultimately a 'gentile or a tax collector'), to an insider, that is, one who is 'regained'. The

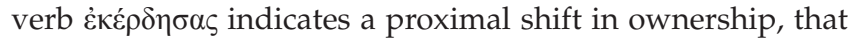
is, to have earned or gained that person for one's self. If the person does not hear, the relational interaction moves from subject-object engagement (one individual UL with another individual UR) to an intersubjective (LL) and interobjective engagement (LR). In verse 16 , the verb $\pi \alpha \rho \alpha \dot{\alpha} \alpha \beta \varepsilon$ indicates that one brings along another with one's self (as in Lk 9.28). The taking of another witness ( $\mu \alpha \rho \tau \dot{\rho} \rho \omega v)$ indicates that the one (or ones) taken along share a common view of the situation (LL). There is a shared thought world concerning the matter that is to be addressed with the sinning party. Their presence is intended to act as a social contract (LL), a confirmation of the sinned against the person's location on the side of righteousness and truth $(\sigma \tau \alpha \theta \tilde{\eta})$. The final progression in the narrative takes the matter to the broader

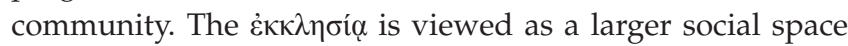
(LL) in which deeper and greater truth about rightness or wrongness can be established and judged. As in Romans 16:16, the use of this term carries a collective identity and shared thought space, so that Paul could say that the

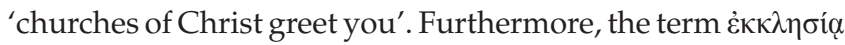
not only establishes communal thought boundaries (LL), that is, the called out ones, which establishes a boundary between the in-group and the out-group, it also has a socio-historical meaning in common usage that derives from before the Christian era in which it refers to a socio-political entity like an assembly (Ac 19:39) based in a city or a state (LR). The conclusion of this narrative in verses $17 \mathrm{~b}-19$ touches on all four quadrants of individual and social identity. In verse $17 \mathrm{~b}$, Matthew states, 'if the offender refuses to listen even to the church, let such a one be to you as a Gentile and a tax collector'. As discussed earlier, the connotation of such a judgement has consequences for the individual being cast out (UR), for their faith (i.e. regarding them as a Gentile, UL), their belonging in the faith community (LL), and for their future social and economic interaction with the community (LR, 'regard them as a tax collector'). Some have suggested

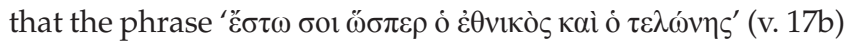
is an act of formal excommunication from the community, while others have said that it may simply have had religious and interpersonal connotations ${ }^{17}$ (Mbabazi 2013:153-158). My own reading of this is that the narrative is framed thematically by some important markers that help us to understand what was meant by this phrase. First, the use of the word $\dot{\alpha} \delta \varepsilon \lambda \varphi{ }^{\prime} \varsigma$ throughout the passage places an emphasis on the depth of the relationship and the importance of engaging the sinner to restore interpersonal harmony. Second, the entire discussion is moved along by its location within the Jewish law and Jesus' reinterpretation thereof for the Matthean community (vv. 21-22) and the expectation of mimicking the mercy of the father (or king) (v.35). Finally, the social, economic and political setting into which the whole of the Gospel of Matthew enters, presents an in-group and an out-group identity (Carter 2005:368; Hagner 1995:532; Mounce 1995:468-469).

The Matthean community is forming its true identity over against those who do not share their social and religious worldview. Naturally there is some scholarly discussion on whether the Matthean community and Matthew were hostile to the out-group or not. It can be suggested that in light of the evangelist's intentions in the Gospel, there is a possibility that the intention and tone of the Gospel speaks of winning over the out-group, rather than an outright rejection of them. Carter (2005:368) points out that Jesus frequented with tax collectors and 'heathens' (Mt 9:9, 10-13; 11:19), and that he saw such persons as the object of mission, 'people to be won over to the community of disciples' (cf. Mounce 1995:468469). Regardless, it is clear that being an outsider was an undesirable social and religious state to be in. Significantly, verses 19-20 and 35 bring in the larger dimension of eternal acceptance or eternal rejection (UL and LL) by God as a result of inclusion or exclusion from the community (UR and LR).

This leads to the next phase in the narrative. This section of the discourse takes on the form of a parable. An approach to understanding parables is to relate certain elements of the parable allegorically to spiritual realities, or spiritualor theological constructs (Blomberg 2009:46). A parable deals with forgiveness as a concept differently from a complex social-juristic process of dealing with discipline in the community (UR, LR), as found in verses 15-20, or the religious

17.Please see Mbabazi's detailed discussion (2013:153-158) of the four general approaches to this topic here. Luz (2005:450-451) has also done an extensive survey of the various approaches to the meaning of this verse in. 
teaching and reframing of a traditional teaching on forgiveness by Jesus (UL, LL) (vv. 21-22). Meaning in a parable relies on the author and the reader sharing a common metaphoric thought structure (LL) that creates meaning for the reader (UL) and can find expression in their individual actions (UL) and affirmation and support within the community (LR) (Carter \& Heil 1998:1-8; Mbabazi 2013:160-163). ${ }^{18}$ The application of the parable, which sums up its intention, is to be found in verse 35 . This verse is helpful in understanding the meaning and intention of the preceding narrative.

In Matthew 18:15-35 we see a link between a social problem (UR, LR), the restoration of an individual and communal relationship (vv. 15-20), the cancelling of a debt (vv. 23-25), and a spiritual reality (UL and LL). Jesus answers Peter's question on forgiveness within the community by sharing a parable that can be likened to 'the Kingdom of heaven

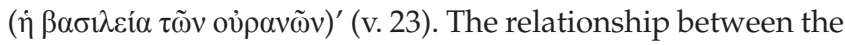
human and the divine, the present and the eschaton, finds expression in the parable of the unforgiving servant in verses 23-35. Here, heaven, and in particular the king of heaven, brackets the discussion: the ' $\beta \alpha \sigma i \lambda \varepsilon i \alpha \tau \tilde{\omega} v$ oủ $\rho \alpha v \tilde{\omega} v^{\prime}$ [Kingdom

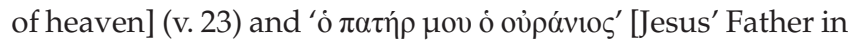
heaven] (v.35).

What this means is, for example, that the $\beta \alpha \sigma \imath \lambda \varepsilon v$ s and кúpı $\varsigma$ in the parable is an analogy for God, not a picture of him; the

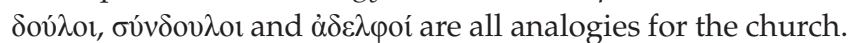
(Mbabazi 2013:161)

Matthew's intention in employing this literary style was thus to evoke shared meaning (LL) in the reader by telling a story that could be concretely related to actual experiences (such as

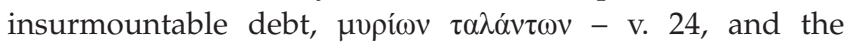

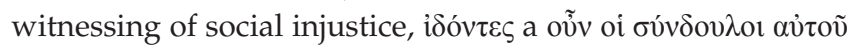
$\tau \grave{\alpha} \gamma \varepsilon v o ́ \mu \varepsilon v \alpha \dot{\varepsilon} \lambda v \pi \eta \dot{\theta} \theta \eta \sigma \alpha v \sigma \varphi \delta \rho \rho-v$. 31). The indented outcome was to draw upon this shared set of community beliefs, to activate a moral and theological change in the individual's

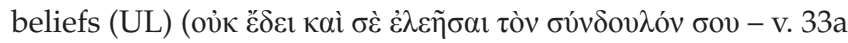

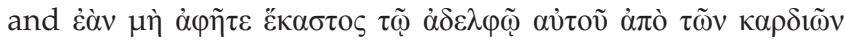
$\dot{v} \mu \tilde{\omega} v-v .35 b)$. This, in turn, would change the behaviour of the reader, encouraging her or him not to act like the unforgiving servant, but indeed to act like the merciful king (UL). When verses 21-22 (which introduces the parable) are coupled with the parable narrative, it is clear to see that the intention is not only to alter individual attitudes (UL) and behaviour (UR), but to establish a new moral and religious order (LL) that will bring harmony among the in-group of the Matthean community (LR). Moreover, when one considers all three parts of the text together (vv. 15-35) the picture becomes still clearer. Without an integrated shift in belief

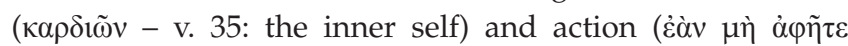

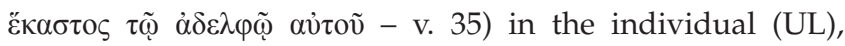

18.A great deal of scholarly work has been done on the genre of parables, their intention and usage in the gospels in general and Matthew's Gospel in particular. intention and usage in the gospels in general and Matthew's Gospel in particular. Hultgren (2002:383-416); Jeremias (2003:82-84); Liebenberg (2001:167-275); Linnemann 1977:167-174); Oppong-Kumi (2013:27-69); Zimmermann (2015); Linnemann 1977:167-174); Oppong-Kumi the harmony of the community (LL) will be eroded (v. 17), the unity of the faith will be weakened (vv. 18-19), and the presence of the Lord in the community will be lost (v. 20). Most importantly, God, the heavenly King and Father, will be displeased (v. 35). The parable elicits in the reader a connection with all four aspects of social and individual identity, individual belief (UL), social values and religious values (LL), individual action (UR), and communal action and social cohesion (LR).

\section{Intercultural Bible reading on forgiveness}

This understanding frames the value of using Matthew 18:15-35 in the intercultural group readings. It is unlikely that any one individual would have a completely integrated understanding of the text (locating meaning in each of the four quadrants and understanding the importance of the interaction between these categories of meaning). However, when a variety of readers engage the text in a safe space, without judgement or competition (Gobodo-Madikizela 2008:169-188), it is possible that the various perspectives of the readers could enrich and deepen each other's understanding of both the text and the communicative intention of the text (mimesis).

Paul Ricoeur (cf. 2009) reminds Christian theologians, including biblical scholars, to be careful of creating a simplistic soteriological short-circuit between remembering and forgiving by calling to mind the eschatological horizon of memory (Junker-Kenny \& Kenny 2004:x). Ricoeur (2003) emphasises the importance of understanding forgiveness as a process of engagement when he writes:

Forgiveness, if it has a meaning and if it exists, constitutes the joint horizon of memory, history and forgetting. The horizon ... puts the stamp of incompleteness on the whole enterprise ... what is at stake is to project a sort of eschatology of memory, and as its consequence, of history and forgetting. (pp. 593, 595)

The important point to recognise is that forgiveness goes beyond a mere mental construct, an understanding of the concepts communicated in the text. Rather, as pointed out in the famous debate on the universality of hermeneutics between Gadamer and Habermas (Negru 2007:113-119), there will always be a difference between what the individual reader or scholar constructs in his or her mind and what the social world constructs as a historical reality.

Ricoeur suggests that what is needed is an act of translation ${ }^{19}$ that can bridge the differences in language and the very ontological nature of difference between self and other (Ricoeur \& Brennan 1995:7). ${ }^{20}$ Kearny (Ricoeur 2007)

19.'Translation can be understood here in both a specific and a general sense. In the specific sense - the one in common contemporary usage - it signals the work of translating the meanings of one particular language into another in the more translating the meanings of one particular language into another. In the more generic sense, it indicates the everyday act of speaking as a way not only of translating oneself (inner to outer, private to public, unconscious to conscious, etc.)
but also more explicitly of translating oneself to others' (Ricoeur 2007:xiv-xv).

20.'The identity of a group, culture, people or nation, is not that of an immutable substance, nor that of a fixed structure, rather, of a recounted story' (Ricoeur \& Brennan 1995:7) 
comments on the necessity for shared translation and forgiveness that it:

... is only when we translate our own wounds in the language of strangers and retranslate the wounds of strangers into our own language that healing and reconciliation can take place. (p. xx)

This possibility of forgiveness is highlighted by an integral, AQAL, hermeneutic approach to the social and spiritual complexity of forgiveness expressed within Matthew 18:15-35.

\section{Conclusion}

This article has attempted to make a case for an integrative AQAL approach to engaging forgiveness in Matthew 18.1535 . The central argument is that a public theological approach to biblical scholarship should seek to develop new knowledge on both the text (within the public of the theological academy), and also to find ways of bridging this knowledge for the contemporary readers (in the public of the church and the public of society at large). The purpose of this engagement is to add new insight to the theological discourse on forgiveness in complex social settings such as those found in South Africa.

Ken Wilber's integral theory (AQAL) highlights the need for a multifaceted understanding of reality in this regard. It suggests that all understanding must take account of the internal life, the external life, the individual as well as the collective. This notion was applied to the text itself to illustrate the layered complexity of forgiveness as an integrative process in Matthew's narrative in 18:15-35. The conclusion is that such a textured and nuanced approach to this passage could open up new possibilities for understanding forgiveness among readers of the text from diverse social, cultural and theological perspectives.

\section{Acknowledgements Competing interests}

The authors declare that they have no financial or personal relationships which may have inappropriately influenced them in writing this article.

\section{References}

Aten, J., O'Grady, K. \& O'Grady Jr, E.W., 2013, The Psychology of Religion and Spirituality for Clinicians: Using Research in Your Practice, Routledge, London.

Austin, J.L. 1975, How to do things with words, Oxford University Press, New York, NY. Bauer, D., 1989, Structure of Matthew's Gospel: A Study in Literary Design, Continuum, New York, NY.

Bernstein, R.J., 2006, 'Derrida: The Aporia of Forgiveness?' Constellations 13(3) 394-406.

Blomberg, C.L., 2009, Interpreting the Parables, InterVarsity Press, Downers Grove, IL.

Brewer, M.B. \& Kramer, R.M., 1985, 'The Psychology of Intergroup Attitudes and Behavior', Annual Review of Psychology 36(1), 219-243.

Byrne, M., 2007, Trauma and Forgiveness: Lessons from South Africa and East Timor, Australian Catholic Social Justice Council, Alexandria, NSW.

Carter, W., 2005, Matthew and the Margins, Bloomsbury Academic, London.

Carter, W. \& Heil, J.P., 1998, Matthew's Parables: Audience-Oriented Perspectives, Catholic Biblical Association of America, Washington, DC.

Davies, W.D. \& Allison, D.C., 1988, A critical and exegetical commentary on the Gospel according to Saint Matthew, vol. 1, T\&T Clark, Edinburgh.

Davies, W.D. \& Allison, D.C., 1991, A critical and exegetical commentary on the gospel according to Saint Matthew, vol. 2, T\&T Clark, Edinburgh.
Daye, R., 2012, Political Forgiveness: Lessons from South Africa, Wipf \& Stock Publishers, Eugene, OR.

De Boer, M.C., 1988, 'Ten Thousand Talents? Matthew's Interpretation and Redaction of the Parable of the Unforgiving Servant (Matt 18:23-35)', Catholic Biblical Quarterly 50(1), 214-232.

De Quincey, C., 2006, Radical Knowing: Understanding Consciousness through Relationship, Inner Traditions/Bear \& Co., San Francisco, CA.

De Wit, J.H., 2012, Empirical Hermeneutics, Interculturality, and Holy Scripture, Institute of Mennonite Studies, Elkhart, IN.

Dreyer, J.S., \& Pieterse, H.J.C., 2010, 'Religion in the public sphere: What can public theology learn from Habermas's latest work?' HTS Teologiese Studies/Theological Studies 66(1), Art. \# 798, 7 pages. http://dx.doi.org/10.4102/hts.v66i1.798

Duffy, M., 2009, Paul Ricoeur's pedagogy of pardon, Continuum, London.

Duling, D.C., 1999, 'Matthew 18:15-17: Conflict, Confrontation, and Conflict Resolution in a 'Fictive Kin' Association', Biblical Theology Bulletin: A Journal of Bible and Theology, 29(1), 4-22.

Esbjörn-Hargens, S., 2009, An overview of integral theory: An all-inclusive framework for the 21st century, Integral Institute, Louisville, CO, viewed 10 October 2010 from https://integrallife.com/integral-post/overview-integral-theory (Resource PaperNo.1).

Forster, D.A., 2006, Validation of individual consciousness in strong artificial intelligence: an African theological contribution, PhD thesis, Department of Systematic Theology, University of South Africa, Pretoria.

Garland, D.E., 1999, Reading Matthew: A Literary and Theological Commentary on the First Gospel, Smyth \& Helwys Publishing Inc., Macon, GA.

Gobodo-Madikizela, P., 2008, 'Trauma, forgiveness and the witnessing dance: Making public spaces intimate', Journal of Analytical Psychology 53(2), 169-188.

Gobodo-Madikizela, P., 2009, 'Working Through the Past: Some Thoughts on Forgiveness in Cultural Context', in P. Gobodo-Madikizela \& C.H. van der Merwe (eds.), Memory, Narrative, and Forgiveness: Perspectives on the Unfinished Journeys of the Past, pp. 148-169, Cambridge Scholars Publishing, Cambridge.

Gowan, D.E., 2010, The Bible on forgiveness, Pickwick Publications, Eugene, OR.

Habermas, J., 1985, The Theory of Communicative Action: Reason and the rationalization of society, Beacon Press, Kansas City, KS

Habermas, J., 1991, The Structural Transformation of the Public Sphere: An Inquiry Into a Category of Bourgeois Society, MIT Press, Cambridge, MA.

Hägerland, T., 2011, Jesus and the Forgiveness of Sins: An Aspect of his Prophetic Mission, Cambridge University Press, Cambridge.

Hagner, D.A., 1995, Word Biblical Commentary, vol. 33b, Matthew 14-28, Thomas Nelson, Dallas, TX.

Hannoum, A., 2005, 'Paul Ricoeur On Memory', Theory, Culture \& Society 22(6), 123-137.

Hermans, C.A.M., 2012, 'Towards a 'U-turn' by the churches: How (Not) to possibilise the future', Religion and Theology 19(3-4), 237-264.

Hofmeyr, J.H. \& Govender, R., 2015, SA Reconciliation Barometer 2015: National Reconciliation, Race Relations, and Social Inclusion, Institute for Justice and Reconciliation, Cape Town.

Hultgren, A.J., 2002, The Parables of Jesus: A Commentary, Wm. B. Eerdmans Publishing, Grand Rapids, MI.

Jeremias, J., 2003, The Parables of Jesus, S.C.M. Press, London.

Jonker, L., 2015, From adequate Biblical interpretation to transformative intercultural hermeneutics: Chronicling a personal journey, Institute of Mennonite Studies, Elkhart, IN

Junker-Kenny, M. \& Kenny, P., 2004, Memory, Narrativity, Self and the Challenge to Think God: The Reception Within Theology of the Recent Work of Paul Ricoeur, LIT Verlag, Münster.

Kaplan, D.M., 2008, Reading Ricoeur, State University of New York Press, New York, NY.

Kearney, R., 2013, 'Forgiveness as the limit: Impossible or possible', in F. O'Rourke (ed.), What happened in and to moral philosophy in the twentieth century: Philisophical essays in honour of Alasdair Macintyre, pp. 305-320, University of Notre Dame Press, Notre Dame, IN.

Kok, J., 2014, 'Social identity complexity theory as heuristic tool in New Testament studies', HTS Teologiese Studies/Theological Studies 70(1), Art. \#2708, 9 pages. http://dx.doi.org/10.4102/hts.v70i1.2708

Konstan, D., 2010, Before Forgiveness: The Origins of a Moral Idea, Cambridge University Press, Cambridge.

Koopman, N., 1998, 'Racism in the Post-Apartheid South Africa', in L. Kretzschmar \& L.D. Hulley (eds.), Questions About Life and Morality: Christian Ethics in South Africa Today, pp. 153-168, J.L. van Schaik Publishers, Pretoria.

Koopman, N., 2011, 'Modes of prophecy in a democracy', in H. Bedford-Strohm \& E. de Villiers (eds.), Prophetic witness: an Appropriate Mode of Public Discourse
in Democratic Societies? Theology in the Public Square/Theologie in der in Democratic Societies? Theology in the
Offentlichkeit, pp. 181-192, LIT Verlag, Berlin.

Lategan, B.C., 2015, Hermeneutics and Social Transformation - A selection from the essays of Bernard C. Lategan, ed. D.J. Smit, Stellenbosch, SUN Press.

Liebenberg, J., 2001, The Language of the Kingdom and Jesus: Parable, Aphorism, and Metaphor in the Sayings Material Common to the Synoptic Tradition and the Gospel of Thomas, Walter de Gruyter, Berlin.

Linnemann, E, 1977, Parables of Jesus: Introduction and Exposition, SPCK, London. Luz, U., 2005, Studies in Matthew, Wm. B. Eerdmans Publishing, Grand Rapids, MI. 
Maluleke, T.S., 2011, 'Reflections and Resources The Elusive Public of Public Theology: A Response to William Storrar', International Journal of Public Theology 5(1) 79-89.

Mbabazi, I.K., 2013, The Significance of Interpersonal Forgiveness in the Gospel of Matthew, Wipf \& Stock Publishers, Eugene, OR.

Morris, L., 1992, The Gospel According to Matthew, Wm. B. Eerdmans Publishing, Grand Rapids, MI.

Mounce, R.H., 1995, Matthew, Hendrickson, Peabody, MA.

Negru, T., 2007, 'Gadamer-Habermas debate and universality of hermeneutics', Cultura: International Journal of Philosophy of Culture and Axiology 4(1) 113-119.

Nel, M.J., 2002, Vergifnis en versoening in die evangelie volgens Matteus, DTh thesis, University of Stellenbosch, Stellenbosch.

Nel, M.J., 2013, 'The Forgiveness of Debt in Matthew 6:12, 14-15', Neotestamentica 47(1), 87-106.

Nel, M.J., 2014, 'Mission and ethics - sensitivity to outsiders in Matthew's mission', in J. Kok \& J.A. Dunne (eds.), Insiders versus outsiders: Exploring the dynamic relationship between mission and ethos in the New Testament, pp. 85-105, Gorgias Press, New Jersey, NJ. (Perspectives on Philosophy and Religious Thought).

Nel, M.J., 2015a, 'Interpersoonlike vergifnis in Matteus 18:15-35', In die Skriflig/In Luce Verbi 49(2), Art. \#1935, 8 pages. http://dx.doi.org/10.4102/ids.v49i2.1935

Nel, M.J., 2015b, 'The motive of forgiveness in the Gospel according to Matthew', In die Skriflig/In Luce Verbi 49(1), Art. \#1917, 9 pages. http://dx.doi.org/10.4102/ids. v49i1.1917

Nussbaum, M.C.C., 2010, Not For Profit: Why Democracy Needs the Humanities, Princeton University Press, Princeton, NJ.

Oppong-Kumi, P.Y., 2013, Matthean Sets of Parables, Mohr Siebeck, Tübingen.

Overman, J.A., 1996, Church and Community in Crisis: The Gospel According to Matthew, Bloomsbury Academic, London.

Paulson, D.S., 2008, 'Wilber's Integral Philosophy: A Summary and Critique', Journal of Humanistic Psychology 48(3), 364-388.

Pettigrew, T.F., 1998, 'Intergroup contact theory', Annual review of psychology 49, 65-78.

Pettigrew, T.F. \& Tropp, L.R., 2011, When groups meet: the dynamics of intergroup contact, Psychology Press, New York, NY.

Reimer, D.J., 1996, 'The apocrypha and biblical theology: The case of interpersonal forgiveness', in J. Barton \& D.J. Reimer (eds.), A er the exile: essays in honour of Rex Mason, pp. 259-282, Mercer University Press, Macon, GA

Ricoeur, P, 2003, La mémoire, I'histoire, l'oubli, Le Seuil, Paris.

Ricoeur, P., 2007, 'Introduction: Ricoeur's philosophy of translation', in Kearney, R (ed.), On Translation, pp. vii-xx, Routledge, New York.

Ricoeur, P., 2009, Memory, History, Forgetting, University of Chicago Press, Chicago, II.

Ricoeur, P. \& Brennan, E., 1995, 'Reflections on a new ethos for Europe', Philosophy \& social criticism 21(5-6), 3-13.

Ruiter, D.J., 2007, 'Notions of the Public and Doing Theology' International Journal of Public Theology 1(3), 431-454.

Scharmer, C.O., 2009, Theory U: Learning from the Future as It Emerges, BerrettKoehler Publishers, San Francisco, CA.

Schneider, K.J., 1987, 'The Deified Self A' "Centaur" Response to Wilber and the Transpersonal Movement', Journal of Humanistic Psychology 27(2), 196-216.

Schneider, K.J., 1989, 'Infallibility Is So Damn Appealing A Reply to Ken Wilber', Journa of Humanistic Psychology 29(4), 470-481.

Schneider, K.J., 2012, 'Existentialism and the transpersonal: A rejoinder', Existentia Analysis 23(1), 120-123.

Searle, J.R., 1969, Speech acts: An essay in the philosophy of language, Cambridge University Press, Cambridge.

Senior, D., 1987, 'Matthew 18:21-35', Interpretation 41(4), 403-407.
Sigurdson, O., 2012, Theology and Marxism in Eagleton and Zizek: A Conspiracy of Hope, Palgrave Macmillan, London.

Sigurdson, O., 2013, 'Slavoj Žižek, the Death Drive, and Zombies: A Theological Account', Modern Theology 29(3), 361-380.

Smit, D.J., 2007, 'What does "Public" mean? Questions with a view to Public Theology', in Hansen, L.D (ed.), Christian in public aims, methodologies, and issues in public theology, pp. 11-47, SUN Press, Stellenbosch.

Smit, D.J., 2013, 'The Paradigm of Public Theology - Origins and Development', in H. Bedford-Strohm, F. Höhne \& T. Reitmeier (eds.), Contextuality and Intercontextuality in Public Theology, pp. 11-23, Lit Verlag, Berlin.

Snyman, K., 2002, Myth, mind, Messiah: exploring the development of the Christian responsibility towards interfaith dialogue from within Ken Wilber's integral hermeneutics, PhD thesis, University of South Africa, Pretoria.

Talbert, C.H., 2010, Matthew, Baker Academic, Grand Rapids, MI.

Taylor, C., 2009, A Secular Age, Harvard University Press, Cambridge, MA.

Tracy, D., 1975, 'Theology as public discourse', The Christian Century 92(10), 287-291.

Tracy, D., 2014, 'Three Kinds of Publicness in Public Theology' International Journal of Public Theology 8(3), 330-334.

Tshaka, R.S., 2014, 'A perspective on notions of spirituality, Democracy, Social cohesion and public theology', Verbum et Ecclesia 35(3), Art. \#1336, 6 pages. $\mathrm{http}: / / \mathrm{dx}$.doi.org/10.4102/ve.v35i3.1336

Tucker, J.B. \& Baker, C.A., 2014, T\&T Clark Handbook to Social Identity in the New Testament, A\&C Black, London.

Tutu, D., 2012, No Future Without Forgiveness, Random House, New York, NY.

Van der Walt, C., 2014, Toward a Communal Reading of 2 Samuel 13, Institute of Mennonite Studies, Elkhart, IN.

Van der Watt, J.G., 2006, 'Ethics and Ethos in the Gospel according to John', Zeitschrift für die Neutestamentliche Wissenchaft und die Kunde der Älteren Kirche 97(2), 147-176.

Van der Watt, J.G., 2013, 'Imitation and ethics in John', paper presented at the International meeting on Christianity and Social Relevance, Potchefstroom, viewed 5 July 2015, from http://repository.ubn.ru.nl.proxy.ubn.ru.nl/handle/ 2066/119840

Van der Watt, J.G., 2014. 'Navolging van Jesus, mimesis en 1 Johannes', In die Skriflig/ In Luce Verbi, 48(1), Art. \#1819, 8 pages. http://dx.doi.org/10.4102/ids.v48i1. 1819

Van der Watt, J.G., \& Malan, F.S., 2006, Identity, ethics, and ethos in the New Testament, Walter de Gruyter, Berlin.

Viljoen, F.P., 2014, 'External cultic tradition and internal ethical purity in Matthew 15', In die Skriflig/In Luce Verbi, 48(1), Art. \#1818, 12 pages. http://dx.doi.org/10.4102/ ids.v48i1.1818

Visser, F., 2003, Ken Wilber: Thought as Passion, SUNY Press, Albany, NY.

Viviano, B., 2007, Matthew and His World: The Gospel of the Open Jewish Christians, Vandenhoeck \& Ruprecht, Göttingen. (Studies in Biblical Theology).

Vosloo, R., 2015, 'Difficult Forgiveness? Engaging Paul Ricoeur on Public Forgiveness within the Context of Social Change in South Africa', International Journal of Public Theology 9(3), 360-378.

Wasserman, H., 2016, 'Listening past difference: Towards a compassionate ethics of communication', Stellenbosch Theological Journal 1(2), 217-228.

Weren, W., 2006, 'The Macrostructure of Matthew's Gospel: A New Proposal', Biblica: Commentarii Periodici Pontificii Instituti Biblici 87, 171-200.

Wilber, K., 1998, The Essential Ken Wilber: An Introductory Reader, 1st edn., Shambhala, Boston, MA.

Wilber, K., 2011, The Eye of Spirit: An Integral Vision for a World Gone Slightly Mad, 3rd edn., Shambhala Publications, Boston, MA.

Zimmermann, R., 2015, Puzzling the Parables of Jesus: Methods and Interpretation, Fortress Press, Minneapolis, MN.

Zimmermann, R. \& Dormeyer, D., 2007, Kompendium der Gleichnisse Jesu, Gütersloher Verlagshaus, München. 